\title{
Oxidant-induced DNA Damage of Target Cells
}

Ingrid Schraufstätter, Paul A. Hyslop, Janis H. Jackson, and Charles G. Cochrane

Department of Immunology, Research Institute of Scripps Clinic, La Jolla, California 92037

\begin{abstract}
In this study we examined the leukocytic oxidant species that induce oxidant damage of DNA in whole cells. $\mathrm{H}_{2} \mathrm{O}_{2}$ added extracellularly in micromolar concentrations (10-100 $\mu \mathrm{M})$ induced DNA strand breaks in various target cells. The sensitivity of a specific target cell was inversely correlated to its catalase content and the rate of removal of $\mathrm{H}_{2} \mathrm{O}_{2}$ by the target cell. Oxidant species produced by xanthine oxidase/purine or phorbol myristate acetate-stimulated monocytes induced DNA breakage of target cells in proportion to the amount of $\mathrm{H}_{2} \mathrm{O}_{2}$ generated. These DNA strand breaks were prevented by extracellular catalase, but not by superoxide dismutase.

Cytotoxic doses of $\mathrm{HOCl}$, added to target cells, did not induce DNA strand breakage, and myeloperoxidase added extracellularly in the presence of an $\mathrm{H}_{2} \mathrm{O}_{2}$-generating system, prevented the formation of DNA strand breaks in proportion to its $\mathrm{H}_{2} \mathrm{O}_{2}$ degrading capacity.

The studies also indicated that $\mathrm{H}_{2} \mathrm{O}_{2}$ formed hydroxyl radical ('OH) intracellularly, which appeared to be the most likely free radical responsible for DNA damage: 'OH was detected in cells exposed to $\mathrm{H}_{2} \mathrm{O}_{2}$; the DNA base, deoxyguanosine, was hydroxylated in cells exposed to $\mathrm{H}_{2} \mathrm{O}_{2}$; and intracellular iron was essential for induction of DNA strand breaks.
\end{abstract}

\section{Introduction}

Oxidants produced by stimulated neutrophils or macrophages induce cell injury and lysis in surrounding target cells in vivo (1-3) as well as in vitro (4-9). With isolated cells, oxidants have been found to induce rapid turnover of the glutathione cycle (9), a fall in ATP levels (8), inhibition of mitochondrial function and glycolytic activity (10), changes in the intracellular ionic composition (11) and the cytoskeleton (12). These changes precede cellular lysis. While proteins, lipids, carbohydrates, DNA, and RNA $(13,14)$ can all be targets of oxidantinduced injury, damage to a small percentage of DNA molecules may bear greater consequence than damage to other cellular components. Low concentrations of $\mathrm{H}_{2} \mathrm{O}_{2}$, less than 100 $\mu \mathrm{M}$ and well within the range reached in the proximity of stimulated leukocytes, induce DNA strand breaks in various target cells (15-17), and stimulated leukocytes develop strand breaks of their own DNA (17). Oxidants produced by stimulated PMN induce sister chromatid exchanges in Chinese

Address reprint requests to Dr. Schraufstatter, Department of Immunology, Research Institute of Scripps Clinic, 10666 North Torrey Pines Road, La Jolla, CA 92037.

Received for publication 16 February 1988 and in revised form 13 April 1988.

J. Clin. Invest.

(c) The American Society for Clinical Investigation, Inc.

$0021-9738 / 88 / 09 / 1040 / 11 \quad \$ 2.00$

Volume 82, September 1988, 1040-1050 hamster ovary cells (18) and lead to malignant transformation in C3H10T $1 / 2$ cells $(19,20)$.

Information about the actual species of oxidant involved in the damage of DNA is limited, however. In radiation-induced DNA damage, the major injurious species of oxidant involved is the hydroxyl radical ( $\mathrm{\circ} O \mathrm{OH})(21,22)$. Similarly, with isolated DNA exposed to $\mathrm{H}_{2} \mathrm{O}_{2}$, the ultimate injurious oxidant is the 'OH (23-25). However, $\mathrm{OH}$ has a half-life of $10^{-9} \mathrm{~s}(26)$, a diffusion radius of $2.3 \mathrm{~nm}(26)$, and reacts indiscriminately with the closest neighboring molecules. This places in question the role of ${ }^{\circ} \mathrm{OH}$ in DNA damage of cells exposed to stimulated leukocytes. While it has been described that phenanthroline can prevent $\mathrm{H}_{2} \mathrm{O}_{2}$-induced DNA strand break formation in 3T3 cells (27), there is little information on the comparative efficacy of various ${ }^{\circ} \mathrm{OH}$ scavengers and $\mathrm{Fe}$-chelators to prevent DNA strand breaks. Still less is known about the species of oxidants formed by stimulated neutrophils that may be responsible for DNA damage of target cells (16).

The purposes of this study are, therefore, to analyze the oxidants, generated in the inflammatory process, that may be responsible for damage of DNA in target cells; to acquire information on the cellular protective systems for oxidant-induced damage of DNA, and to examine the capacity of cells to recover from oxidant-induced DNA damage.

\section{Methods}

\section{Procedures}

Cell culture. P388 D1 murine macrophage-like tumor cells were cultured in RPMI 1640 medium (Irvine Scientific, Santa Ana, CA) supplemented with $10 \%$ fetal calf serum (Hyclone Laboratories, Logan, UT), $2 \mathrm{mM}$ L-glutamine and $50 \mu \mathrm{g} / \mathrm{ml}$ gentamycin sulfate (MA Bioproducts, Walkersville, MD). Cells were harvested by shaking, centrifuged at $400 \mathrm{~g}$ for $5 \mathrm{~min}$, and resuspended in RPMI 1640 or in modified Gey's buffer (MGB': $147 \mathrm{mM} \mathrm{NaCl} / 5 \mathrm{mM} \mathrm{KCl}, 1.5 \mathrm{mM} \mathrm{CaCl}_{2}$, $1.9 \mathrm{mM} \mathrm{KH}_{2} \mathrm{PO}_{4} / 0.3 \mathrm{mM} \mathrm{MgCl} / 1.1 \mathrm{mM} \mathrm{Na} 2 \mathrm{HPO}_{4} / 10 \mathrm{mM}$ Hepes/ $5.5 \mathrm{mM}$ glucose, $\mathrm{pH}$ 7.4).

GM 1380 human fetal lung fibroblasts were grown in DME (Irvine Scientific) containing 10\% FCS, $2 \mathrm{mM}$ glutamine and penicillin/streptomycin. At confluency the cells were trypsinized (trypsin/EDTA; Gibco Laboratories, Grand Island, NY) for $1 \mathrm{~min}$ at $37^{\circ} \mathrm{C}$, washed in $10 \%$ FCS at $300 \mathrm{~g}$ for $5 \mathrm{~min}$, and resuspended in DME or MGB.

Human peripheral lymphocytes were prepared from fresh acid citrate dextrose (ACD) blood after removal of platelet-rich plasma on lymphocyte separation medium (Litton Bionetics, Kensington, MD) (28). After lysis of contaminating erythrocytes in $154 \mathrm{mM} \mathrm{NH}_{4} \mathrm{Cl}, 12$ $\mathrm{mM} \mathrm{NaH} \mathrm{CO}_{3}, 0.1 \mathrm{mM} \mathrm{Na} 2 \mathrm{EDTA}$, pH 7.4, the cells were washed once in MGB. The cells were either used at this stage as mononuclear cells (70-75\% lymphocytes, $25-30 \%$ monocytes) or resuspended in

1. Abbreviations used in this paper: $\mathrm{ACD}$, acid citrate dextrose; AT, aminotriazole; BHT, butylated hydroxytoluene; BSO, buthionine sulfoximine; CuDIPS, copper diisopropylsalicylic acid; DFO, desferrioxamine; DFT, desferrithiocine; DHBA, dihydroxybenzoic acid; DMPO, dimethyl pyroline $N$-oxide; DMTU, dimethylthiourea; MGB, modified Gey's buffer; PMA, phorbol myristate acetate; XO, xanthine oxidase. 
DME containing 10\% FCS and incubated in 150-ml tissue culture flasks for $2 \mathrm{~h}$ at $37^{\circ} \mathrm{C}$. Nonadherent cells were $98 \%$ viable and $95 \%$ lymphocytes.

Human PMN were prepared from fresh ACD blood by counterflow centrifugal elutriation as previously described (29). The cell preparation was $98 \%$ pure and at least $98 \%$ viable. Neutroplasts were prepared essentially by the method of Roos et al. (30) except that $10 \mu \mathrm{g} / \mathrm{ml}$ dihydrochalasin $B$ was used as the cytoskeletal disruptor rather than cytochalasin (78).

Rabbit alveolar macrophages were obtained from 2.0 to $2.5 \mathrm{~kg}$ NZW rabbits. Immediately after the animals were killed with $60 \mathrm{mg} / \mathrm{kg}$ pentobarbital (Diabutol), the lungs were lavaged four times with $35-\mathrm{ml}$ aliquots of PBS, pH 7.4. The cells were centrifuged at $400 \mathrm{~g}$ for $5 \mathrm{~min}$, erythrocytes were lysed as described above, and the cells were washed once in MGB. The cells were at least $96 \%$ viable and > 90\% macrophages.

Cell viability was determined by trypan blue exclusion.

Determination of DNA strand breaks. The formation of DNA strand breaks in $2-5 \times 10^{6}$ cells was measured by alkaline unwinding and determination of ethidium bromide fluorescence on a 650-15 spectrofluorometer (Perkin-Elmer, Norwalk, CT) with excitation at $520 \mathrm{~nm}$ and emission at $590 \mathrm{~nm}(15,31)$. Under the conditions employed, ethidium bromide binds preferentially to double-stranded DNA. After oxidant exposure at $37^{\circ} \mathrm{C}$, the cells were centrifuged for 10 $\mathrm{s}$ in a microfuge, resuspended in ice-cold $250 \mathrm{mM}$ myo-inositol, 10

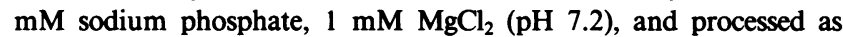
described $(15,16)$. Results are expressed as $D$ (percent double-stranded DNA $)=\left(F-F_{\min }\right) /\left(F_{\max }-F_{\min }\right) \times 100$, where $F$ is the fluorescence of the sample, $F_{\min }$ the background fluorescence determined in samples sonicated at the beginning of the unwinding period to induce maximal DNA unwinding, and $F_{\max }$ is the fluorescence of samples kept at $\mathrm{pH}$ 11.0 , which is below the $\mathrm{pH}$ needed to induce unwinding of DNA.

Electrochemical HPLC detection of ${ }^{\circ} \mathrm{OH}$. ${ }^{\circ} \mathrm{OH}$ was detected by electrochemical HPLC determination of hydroxylation products of salicylate (32). To prevent metal-catalyzed extracellular formation of ${ }^{\circ} \mathrm{OH}$, all solutions were batch treated with chelex 100 (Bio-Rad Laboratories, Richmond, CA), the $\mathrm{pH}$ was adjusted to 7.4 , and the solutions were then dialyzed in new plastic tubes against $1 \%$ ovalbumin to remove trace iron. $7 \times 10^{6} \mathrm{P} 388 \mathrm{D} 1$ cells were incubated for $30 \mathrm{~min}$ in the presence of $5 \mathrm{mM}$ salicylate in $\mathrm{PBS} . \mathrm{H}_{2} \mathrm{O}_{2}$ and scavengers were added. Cellular protein was precipitated by the addition of $0.5 \%$ TCA and the supernatant after centrifugation was injected immediately on an ESA coulochem 5100 A electrochemical detector (det. 1 setting at $0.25 \mathrm{~V}$ ) connected to a Perkin-Elmer HPLC (series 4). Separation of dihydroxybenzoic acid (DHBA) compounds was achieved with 30 $\mathrm{mM} \mathrm{Na-acetate} / 30 \mathrm{mM}$ citric acid, $\mathrm{pH} 3.8$ on a Vydac $\mathrm{C} 18$ column at a flow rate of $0.8 \mathrm{ml} / \mathrm{min}$. Standard 2,5-DHBA eluted with a retention time of $12.7 \mathrm{~min}$, 2,3-DHBA (both from Sigma Chemical Co., St. Louis, MO) of $13 \mathrm{~min}$. Peak heights of the sum of the 2,3- and 2,5DHBA peaks were used to quantitate the $\mathrm{OH}$ trapped.

Electrochemical HPLC detection of 8-hydroxydeoxyguanosine. 1 $\times 10^{8} \mathrm{P} 388 \mathrm{D} 1$ cells were exposed to $\mathrm{H}_{2} \mathrm{O}_{2} \pm$ catalase for $10 \mathrm{~min}$ at $37^{\circ} \mathrm{C}$. The cells were centrifuged for $3 \mathrm{~min}$ at $500 \mathrm{~g}$ at $4^{\circ} \mathrm{C}$. The resulting cell pellet was suspended in $5 \mathrm{ml} \mathrm{SSC}(150 \mathrm{mM} \mathrm{NaCl}, 15 \mathrm{mM}$ sodium citrate, $\mathrm{pH} 7.0$ ) and lysed by the addition of $0.5 \%$ SDS (final concentration). DNA was purified by $\mathrm{RNase/protease} \mathrm{K}$ digestion and phenol extraction (33). The DNA yield for $10^{8}$ cells was around $0.5 \mathrm{mg}$ (determined by absorbance at $260 \mathrm{~nm}$ ). Trace phenol, which interfered with the electrochemical detection of 8-hydroxydeoxyguanosine, was removed by evaporating the samples under $\mathrm{N}_{2} .0 .3 \mathrm{mg}$ DNA was digested with $1 \mu l$ nuclease $P_{1}$ (Bethesda Research Laboratories (BRL), Gaithersburg, MD) for $30 \mathrm{~min}$ at $37^{\circ} \mathrm{C}$ at pH 5.0, followed by a 60 -min digestion at $45^{\circ}$ with $1 \mu \mathrm{l}$ alkaline phosphatase (BRL) at $\mathrm{pH} 8.0$ achieved by the addition of $10 \mu \mathrm{l} 1 \mathrm{M}$ Tris (pH 8.0). 8-Hydroxydeoxyguanosine was determined by electrochemical detection $(34,35)$. $100-\mu 1$ samples were injected onto a Vydac C18 column (The Separations Group, Hesperia, CA) connected to HPLC. 8-Hydroxydeoxyguanosine was determined electrochemically on a coulocomb
5100 detector (ESA, Bedford, MA). Deoxyguanosine used as an internal standard was detected by its ultraviolet absorbance at $256 \mathrm{~nm}$. The 8-hydroxydeoxyguanosine standard was obtained by incubating deoxyguanosine in the presence of $\mathrm{FeSO}_{4}$ /ascorbate (34). Its extinction coefficient at $245 \mathrm{~nm}$ was described as $12,300 \mathrm{M}^{-1} \mathrm{~cm}^{-1}$ (34).

Assay of $\mathrm{H}_{2} \mathrm{O}_{2}$ in cell supernatants. $\mathrm{H}_{2} \mathrm{O}_{2}$ in the cell supernatant was assayed by fluorescence spectroscopy utilizing the peroxidaseparahydroxyphenyl acetic acid (PHPA) assay (36). The spectrophotometric conditions have previously been described (37). Aliquots of supernatant were added to the assay media such that $\mathrm{H}_{2} \mathrm{O}_{2}$ concentrations were $\sim 40 \mu \mathrm{M}$. Standard $\mathrm{H}_{2} \mathrm{O}_{2}$ solutions were used to quantitate measurements.

In some experiments, when myeloperoxidase was added, the amount of $\mathrm{H}_{2} \mathrm{O}_{2}$ was determined by the ferrithiocyanate method (38). Cell samples were TCA precipitated, and $1.8 \mathrm{mM}$ ferrous sulfate and $2.3 \mathrm{mM}$ potassium thiocyanate (final concentrations) were added to $200-\mu 1$ aliquots of supernatant. Absorbance at $490 \mathrm{~nm}$ was read on Titertek plates.

Determination of cellular iron. $2 \times 10^{7} \mathrm{P} 388 \mathrm{D} 1$ cells were washed twice with iron-free PBS prepared as described for ${ }^{\circ} \mathrm{OH}$ detection. The cell pellet was dissolved in $300 \mu \mathrm{l} 2 \%$ SDS, and analyzed by atomic absorption in the laboratory of Dr. D. Bailey (University of California at San Diego). The iron content of the cell-free SDS solution was subtracted from that of the cell pellets.

Determination of cellular antioxidants. Catalase activity was determined in cell sonicates of $0.5-2 \times 10^{7}$ cells by following the disappearance of $33 \mathrm{mM} \mathrm{H} \mathrm{H}_{2} \mathrm{O}_{2}$ at $240 \mathrm{~nm}$ on a spectrophotometer (Gilford Instruments, Inc., Oberlin, $\mathrm{OH})(39)$.

SOD, glutathione peroxidase, and glutathione were measured as previously described $(9,40-43)$.

Glutathione depletion was achieved by incubating cells for $18 \mathrm{~h}$ with $0.2 \mathrm{mM}$ buthionine sulfoxamine (Chemical Dynamics Corp., South Plainfield, NJ) as previously described $(9,44)$.

Myeloperoxidase activity was determined by measuring the $\mathrm{OD}_{415}$ of $200 \mu \mathrm{M}$ ABTS in the presence of $3.85 \mathrm{mM} \mathrm{H}_{2} \mathrm{O}_{2}$ and sample in 100 $\mathrm{mM}$ citrate buffer, $\mathrm{pH} 4.2$ after a $10-20$-min incubation period at room temperature. Absorbance was read on an EIS autoreader (model EL 310; Biotek Instruments) and compared to a standard of human myeloperoxidase (Calbiochem-Behring Co., La Jolla, CA) (45).

Vitamin E was measured by HPLC as described by Fariss et al. (46). In short, $1 \times 10^{8} \mathrm{P} 388 \mathrm{D} 1$ cells were hexane extracted. The extract was applied to a C18 column connected to an HPLC and detected fluorometrically (excitation $205 \mathrm{~nm}$, emission $300 \mathrm{~nm}$ ) on a 650-15 spectrofluorometer.

Determination of poly-ADP-ribose-polymerase activity. Poly-ADPribose polymerase was determined as previously described $(15,47)$ on $5 \times 10^{6}$ lymphocytes incubated with $1 \mu \mathrm{Ci}\left[{ }^{3} \mathrm{H}\right]$ NAD in the presence of $0.01 \%$ digitonin for $5 \mathrm{~min}$ at $37^{\circ} \mathrm{C}$, followed by TCA precipitation and scintillation counting.

\section{Materials}

Ethidium bromide, aminotriazole, catalase, alpha-tocopherol acetate, 2,3- and 2,5 DHBA, PMA, xanthine oxidase (XO), and glucose oxidase, SOD, and DMPO were obtained from Sigma Chemical Co. DMPO was filtered over charcoal (48) and quantitated according to its $e_{226}=7.22 \mathrm{mM}^{-1} \mathrm{~cm}^{-1}$. 2,3- and 2,5-DHBA were made up freshly in $0.5 \%$ TCA. $\mathrm{H}_{2} \mathrm{O}_{2}$ was from Fisher Scientific Co. (Pittsburgh, PA), DMTU from Alfa Scientific Inc., Hayward, CA, and Tiron from Aldrich Chemical Co. (Milwaukee, WI). Human MPO was a product of Calbiochem, and PM2 phage DNA from Boehringer Mannheim Biochemicals (Indianapolis, IN). Desferroxamine and desferrithiocine were supplied by Ciba-Geigy (Basel, Switzerland).

[ ${ }^{3} \mathrm{H}$ ]NAD (sp act $25 \mathrm{Ci} / \mathrm{mmol}$ ) was obtained from ICN (Irvine, $\mathrm{CA}$ ).

Reagents for the extraction of DNA were obtained from the following sources: pronase and phenol from Boehringer Mannheim, and RNAse from Worthington Biochemical Co. (Freehold, NJ). Nuclease $P_{1}$ and alkaline phosphatase were from BRL. 
$\mathrm{HOCl}$ was obtained as Clorox, the $\mathrm{pH}$ was adjusted to 7.4 with $\mathrm{H}_{2} \mathrm{SO}_{4}$. The $\mathrm{HOCl}$ was then glass distilled and quantitated by its $\mathrm{e}_{235}$ $=100 \mathrm{M}^{-1} \mathrm{~cm}^{-1}$ (49).

\section{Results}

Determination of the extracellular oxidants responsible for DNA damage in cells

Effect of $\mathrm{H}_{2} \mathrm{O}_{2}$ on DNA damage in various target cells. Previous results together with those of the present study indicate that small doses of $\mathrm{H}_{2} \mathrm{O}_{2}$ cause DNA strand breaks in P388 D1 cells and human peripheral lymphocytes (15). The formation of DNA strand breaks is observed as early as $30 \mathrm{~s}$ after the addition of $\mathrm{H}_{2} \mathrm{O}_{2}$ (15) and is maximal within $5 \mathrm{~min}$. The number of strand breaks observed when cells were exposed to oxidant at $4^{\circ} \mathrm{C}$ were similar to those at $37^{\circ} \mathrm{C}$ (results not shown).

When the susceptibility to $\mathrm{H}_{2} \mathrm{O}_{2}$ induced DNA strand breaks was investigated in various target cells (human peripheral lymphocytes, P388 D1 cells, GM 1380 fibroblasts, human PMN and rabbit alveolar macrophages) it was observed that there was almost an order of magnitude difference in susceptibility to $\mathrm{H}_{2} \mathrm{O}_{2}$-induced DNA strand breaks in these cells, with the lymphocyte showing apparent half-maximal DNA strand breakage at $18 \mathrm{uM} \mathrm{H} \mathrm{H}_{2} \mathrm{O}_{2}$ and the macrophage at $\sim 100 \mu \mathrm{M}$ (Fig. $1 A$ ).

The susceptibility to $\mathrm{H}_{2} \mathrm{O}_{2}$ correlated inversely with the half-life of $\mathrm{H}_{2} \mathrm{O}_{2}$ in each particular cell: Table I shows the $t_{1 / 2}$ for $1 \mathrm{mM} \mathrm{H} \mathrm{m}_{2}$, the cellular catalase content and the concentration of $\mathrm{H}_{2} \mathrm{O}_{2}$ needed to induce apparent half-maximal numbers of DNA strand breaks in various target cells. The higher resistance to $\mathrm{H}_{2} \mathrm{O}_{2}$-induced DNA damage in cells with high catalase content suggested that cellular catalase was protective.

We then determined whether inhibition of intracellular catalase in each cell type would render the cells equally susceptible to DNA strand breaks induced by $\mathrm{H}_{2} \mathrm{O}_{2}$. When cells were preincubated with $5 \mathrm{mM}$ azide or $12 \mathrm{mM}$ aminotriazole (AT) for $1 \mathrm{~h}$ before the addition of $\mathrm{H}_{2} \mathrm{O}_{2}$, which resulted in $\geq 95 \%$ inactivation of catalase (Table $\mathrm{I}$ ), the dose response in these various cells became the same, and as little as $10 \mu \mathrm{M} \mathrm{H}_{2} \mathrm{O}_{2} / 2$
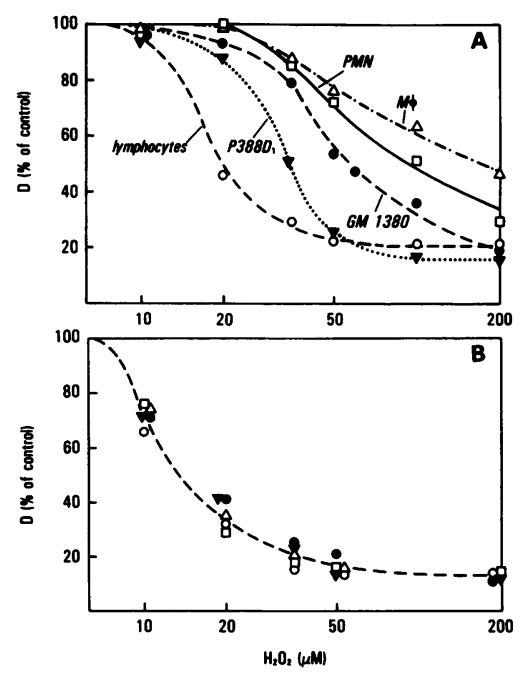

Figure 1. DNA strand breaks induced by $\mathrm{H}_{2} \mathrm{O}_{2}$ in various target cells: 2 $\times 10^{6} / \mathrm{ml}$ human peripheral lymphocytes, P388D1 cells, GM1380 fibroblasts, human PMN or rabbit alveolar macrophages were incubated with a bolus of $\mathrm{H}_{2} \mathrm{O}_{2}$ in the concentrations shown on the abscissa for $5 \mathrm{~min}$ at $37^{\circ} \mathrm{C}$. Cells in B were preincubated with 12.8 mM 3-amino, 1,2,4triazole for $1 \mathrm{~h}$ at $37^{\circ} \mathrm{C}$ before the addition of $\mathrm{H}_{2} \mathrm{O}_{2}$ which led to complete inactivation of

catalase. DNA strand breaks were determined as described $(15,31)$. The symbols in B represent the same cell types as those labeled in A. Mean of three experiments in quadruplicate.
Table I. Correlation between Cellular Catalase Content and Susceptibility to DNA Strand Breaks Induced by $\mathrm{H}_{2} \mathrm{O}_{2}$ in Various Target Cells

\begin{tabular}{lccc}
\hline \multicolumn{1}{c}{ Cell } & $D_{\text {so }}$ & Catalase content & $t_{1 / 2} \mathrm{H}_{2} \mathrm{O}_{2}$ \\
\hline & $\mu M \mathrm{H}_{2} \mathrm{O}_{2}$ & $n g / 10^{6}$ cells & $\min$ \\
Macrophage & 170 & 850 & 0.8 \\
PMN & 94 & 503 & 2.5 \\
GM1380 & 58 & 213 & 5.5 \\
P388D1 & 35 & 20 & 14.0 \\
Lymphocyte & 20 & 4 & 24.0 \\
Macrophage & & & \\
$\quad$ + 12 mM AT & 13.5 & $<2$ & 120.0 \\
& & &
\end{tabular}

$D_{50}$ represents the concentration of $\mathrm{H}_{2} \mathrm{O}_{2}$ that led to unwinding in alkali of $50 \%$ of the DNA as extrapolated from the results shown in Fig. 1. Catalase content in supernatants of cell sonicates from 5-20 $\times 10^{6}$ cells was determined by following the disappearance of $\mathrm{H}_{2} \mathrm{O}_{2}$ at $240 \mathrm{~nm}$ spectrophotometrically (37). The half-life of $\mathrm{H}_{2} \mathrm{O}_{2}$ was measured using the PHPA assay as described. $2 \times 10^{6}$ cells $/ \mathrm{ml}$ were exposed to $1 \mathrm{mM} \mathrm{H}_{2} \mathrm{O}_{2}$. At time intervals $10-50-\mu \mathrm{l}$ samples were added to the PHPA assay mixture and the fluorescent product was quantified.

$\times 10^{6}$ cells was sufficient to induce measurable DNA strand breaks (Fig. $1 \mathrm{~B}$ ). The data also suggest that, since $\mathrm{H}_{2} \mathrm{O}_{2}$ is the prime target of catalase, $\mathrm{H}_{2} \mathrm{O}_{2}$ itself is the major oxidant that penetrates cells to induce DNA strand breaks.

The protection of DNA strand breaks by intracellular catalase underscores the importance of catalase in the protection of DNA from oxidant attack. In the cells with AT-inactivated catalase, SOD and glutathione peroxidase were not inhibited, although in neutrophils, myeloperoxidase was completely inactivated. Depletion of $90-95 \%$ of the cellular glutathione achieved by overnight incubation with BSO $(9,44)$ had no effect on DNA strand break formation in P388 D1 cells. However, when GM 1380 fibroblasts were depleted of glutathione an increase in $\mathrm{H}_{2} \mathrm{O}_{2}$ induced DNA strand breaks was observed (see Fig. $4 \mathrm{~A}$ ). Thus although catalase was a major cellular defense mechanism preventing $\mathrm{H}_{2} \mathrm{O}_{2}$ induced DNA strand breaks, the glutathione cycle also could contribute to inhibiting $\mathrm{H}_{2} \mathrm{O}_{2}$ from forming DNA strand breaks.

Since DNA strand breaks measured after alkali treatment determine the sum of DNA damage induced by direct deoxyribose cleavage, excision repair following base-damage, and cleavage occurring in alkali at apurinic or apyridinic sites, it seemed essential to determine whether base damage was induced by $\mathrm{H}_{2} \mathrm{O}_{2}$ treatment of cells. When $1 \times 10^{8} \mathrm{P} 388 \mathrm{D} 1$ cells were exposed to $250 \mu \mathrm{M} \mathrm{H}_{2} \mathrm{O}_{2}$ for $10 \mathrm{~min}$ at $37^{\circ} \mathrm{C}$ a three- to fourfold increase in 8-hydroxydeoxyguanosine concentrations could be detected (Table II). Catalase prevented the formation of 8-hydroxydeoxyguanosine.

\section{The capacity of various oxidants to induce DNA strand} breaks in whole cells

Stimulated monocytes, XO/purine, glucose oxidase/glucose, and $\mathrm{HOCl}$. The previous results indicated that extracellular $\mathrm{H}_{2} \mathrm{O}_{2}$ was sufficient to induce DNA strand breaks in whole cells. When neutrophils, monocytes or macrophages are stimulated, however, various other oxidant species are formed $\left(\mathrm{O}_{2}^{-}\right.$, $\mathrm{HOCl}$, lipid peroxides) that may induce additional damage. To 
Table II. DNA Base Hydroxylation Induced by Oxidants in Target Cells

\begin{tabular}{lc}
\hline & $8-\mathrm{OHdG} / \mathrm{dG} \times 10^{-5}$ \\
\hline P388D1 Cells plus: & \\
Control & $0.52 \pm 0.09$ \\
$250 \mu \mathrm{M} \mathrm{H} \mathrm{O}_{2}$ & $4.0 \pm 1.3$ \\
$250 \mu \mathrm{M} \mathrm{H}_{2} \mathrm{O}_{2}+250,000 \mathrm{U}$ catalase & 0.8 \\
\hline
\end{tabular}

$1 \times 10^{8}$ cells $\left(2 \times 10^{6} / \mathrm{ml}\right)$ were exposed to $250 \mu \mathrm{M} \mathrm{H}_{2} \mathrm{O}_{2}$ for $10 \mathrm{~min}$ at $37^{\circ} \mathrm{C} .8$-hydroxydeoxyguanosine was determined by electrochemical detection of DNA digests. Deoxyguanosine (dG) eluted at 10.1 min, 8-hydroxydeoxyguanosine (8-OHdG) at $14.2 \mathrm{~min}$. The 8$\mathrm{OHdG} / \mathrm{dG}$ ratio was calculated from standard curves obtained with 1,000-fold higher concentrations of 8-OHdG assuming an $e_{245}$ $=12,300 \mathrm{M}^{-1} \mathrm{~cm}^{-1}(34)$ and an $\mathrm{e}_{256}=13,700 \mathrm{M}^{-1} \mathrm{~cm}^{-1}$ for $\mathrm{dG}$. Mean and standard deviation of three experiments.

evaluate the role of these oxidants, human peripheral mononuclear cells (75\% lymphocytes, $25 \%$ monocytes, $\sim 1 \% \mathrm{PMN}$ ) were exposed to 10-100 ng PMA, which after a lag period of 1-2 min induced a linear production of $\mathrm{H}_{2} \mathrm{O}_{2}$ during the first $20 \mathrm{~min}$ as measured by the PHPA assay. $100 \mathrm{ng}$ PMA, e.g., caused the formation of $2 \mathrm{nmol} \mathrm{H}_{2} \mathrm{O}_{2} / \mathrm{min}$ in $2 \times 10^{6}$ mononuclear cells. Alternatively, $\mathrm{O}_{2}^{-}$and/or $\mathrm{H}_{2} \mathrm{O}_{2}$ were formed enzymatically from XO/purine or glucose oxidase/glucose. Equimolar concentrations of $\mathrm{H}_{2} \mathrm{O}_{2}$ produced by these different systems, induced equivalent numbers of DNA strand breaks (Fig. 2) indicating a correlation between the concentration of $\mathrm{BH}_{2} \mathrm{O}_{2}$ and the formation of DNA strand breaks during the time period tested. The addition of 5,000 $\mathrm{U}$ catalase completely prevented DNA strand breaks induced by $\mathrm{XO} /$ purine, whereas $1 \mathrm{mg} / \mathrm{ml}$ SOD had no protective effect.

$20-200 \mu \mathrm{M} H O C l$ added to $2 \times 10^{6} \mathrm{P} 388 \mathrm{D} 1$ cells failed to induce DNA strand breaks after 5-45 min exposure. The cells were killed by doses of $\mathrm{HOCl}$ above $75 \mu \mathrm{M}$ and yet DNA strand breaks failed to occur.

DNA damage in target cells by stimulated neutroplasts and neutrophils. To differentiate between effector and target cell DNA, stimulated neutroplasts rather than neutrophils were

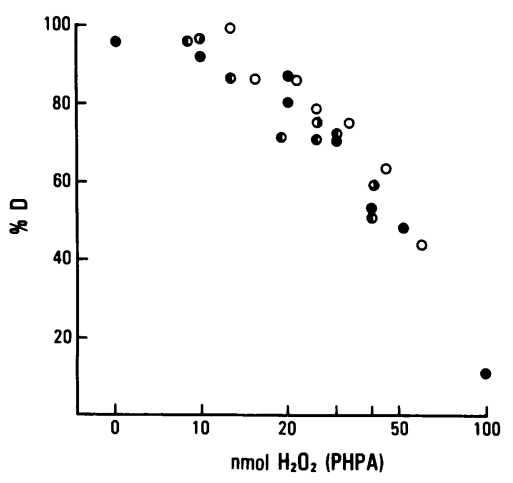

Figure 2. Effect of various oxidants on DNA strand break formation in human mononuclear cells: $5 \times 10^{6}$ mononuclear cells $(75 \%$ lymphocytes, $25 \%$ monocytes) were exposed to a bolus of $\mathrm{H}_{2} \mathrm{O}_{2}(\bullet)$, glucose oxidase/glucose (O), $\mathrm{XO} /$ purine (o), or different doses of PMA (o) for $30 \mathrm{~min}$ at $37^{\circ} \mathrm{C}$. In parallel samples, the concentration of $\mathrm{H}_{2} \mathrm{O}_{2}$ produced during this period of time and the formation of DNA strand breaks were determined. Symbols represent single data points in one experiment. Similar results were obtained in three additional experiments. Slight differences in $\mathrm{H}_{2} \mathrm{O}_{2}$ production as well as susceptibility to oxidant-induced DNA strand breaks precluded the calculation of standard deviations. used as the source of oxidants and DNA strand breaks were determined in peripheral lymphocyte target cells. $5 \times 10^{6}$ neutroplasts stimulated with $100 \mathrm{ng} / \mathrm{ml}$ PMA produced $83.7 \mathrm{nmol}$ $\mathrm{H}_{2} \mathrm{O}_{2} / \mathrm{h}$, and induced unwinding of $92 \%$ of the lymphocyte DNA (Table III). PMA induced a small number of DNA strand breaks in lymphocytes alone (Table III) and led to the formation of small amounts of $\mathrm{H}_{2} \mathrm{O}_{2}$, presumably due to contamination of the lymphocyte preparation with PMNs or monocytes. Up to $5 \%$ monocytes and $1 \%$ PMNs were usually seen in the lymphocyte preparation. Catalase inhibited the formation of DNA strand breaks, while SOD showed no effect.

Since neutroplasts lack certain proteins of the oxidant producing pathways (myeloperoxidase, lactoferrin) that are present in whole PMNs, it was important to assess the capacity of stimulated, intact PMNs to induce DNA damage. However, it was technically unfeasible to separate PMNs and lymphocytes with quantitative yields to allow determination of DNA strand breaks in the lymphocyte only. Therefore, activation of lymphocyte poly-ADP-ribose polymerase was used as an indirect measure of DNA strand breaks in a mixed PMN/lymphocyte system. Poly-ADP-ribose polymerase is activated whenever DNA strand breaks occur (47), and PMNs do not contain detectable poly-ADP-ribose polymerase activity. Thus activation of poly-ADP-ribose polymerase determined in a mixed lymphocyte/PMN system represents activation of this enzyme in the lymphocyte only, and can be used as an indirect measure of DNA strand breaks in the lymphocyte.

When a mixture of $5 \times 10^{6}$ lymphocytes and $5 \times 10^{6}$ PMNs was stimulated with $100 \mathrm{ng}$ PMA, a fivefold increase of poly-ADP-ribose polymerase activity was observed $(15$, and Table IV). The small release of $\mathrm{H}_{2} \mathrm{O}_{2}$ in the lymphocyte preparation with PMA stimulation probably is on the basis of monocyte contamination. When lymphocytes were exposed to 2 $\mathrm{mU} / \mathrm{ml} \mathrm{XO}$ and $1 \mathrm{mM}$ purine, which produced $90 \mathrm{nmol} \mathrm{H}_{2} \mathrm{O}_{2}$ during the first $30 \mathrm{~min}$, an 11-fold increase in poly-ADP-ribose polymerase was observed. This increase in poly-ADP-ribose polymerase activity could be prevented by adding increasing amounts of myeloperoxidase. When the concentration of myeloperoxidase was sufficient to scavenge $95 \%$ of the $\mathrm{H}_{2} \mathrm{O}_{2}$ formed no increase in poly-ADP-ribosylation was observed. The concentration range of MPO added was within the range available in the proximity of stimulated neutrophils when contacting target cells. For comparison, $5 \times 10^{6}$ neutrophils contained a total of 190 mU MPO. Poly-ADP-ribose polymerase activation could similarly be prevented when PMA-stimulated neutroplasts were reconstituted with MPO, although slightly higher concentrations of MPO were necessary (Fig. 4 $B)$. MPO similarly prevented the formation of DNA strand breaks in lymphocytes exposed to xanthine oxidase/purine with complete prevention achieved at $80 \mathrm{mU}$ MPO.

Up to $1 \mu \mathrm{M}$ iron-saturated lactoferrin (studies performed in conjunction with Dr. H. Jacobs, University of Minnesota) had no effect on activation of poly-ADP-ribose polymerase or on the formation of DNA strand breaks measured in lymphocytes exposed to either $\mathrm{XO} /$ purine or stimulated neutroplasts under the same conditions as in the MPO experiments noted above.

These results indicate that $\mathrm{H}_{2} \mathrm{O}_{2}$ is the major extracellular product of the respiratory burst that leads to the formation of DNA strand breaks or DNA damage (as measured by poly ADP ribose polymerase stimulation) in target cells. They also fail to show a DNA damaging effect of $\mathrm{HOCl}$ added or gener- 
Table III. Formation of DNA Strand Breaks in Lymphocytes Exposed to PMA-stimulated Neutroplasts and Prevention by Antioxidants and Metal Chelation

\begin{tabular}{|c|c|c|c|c|c|}
\hline Lymphocytes & PMA & Neutroplasts & Antioxidant & Double-stranded DNA & $\mathrm{H}_{2} \mathrm{O}_{2}$ \\
\hline $2.5 \times 10^{6}$ & $100 \mathrm{ng} / \mathrm{ml}$ & $5 \times 10^{6}$ & & $\% D$ & $n m o l / h$ \\
\hline+ & - & - & - & $92.8 \pm 4.1$ & $0.1 \pm 0.1$ \\
\hline+ & + & - & - & $74.2 \pm 4.9$ & $13.5 \pm 9.9$ \\
\hline+ & - & + & - & $87.1 \pm 1.5$ & $5.2 \pm 6.9$ \\
\hline+ & + & + & - & $7.6 \pm 4.6$ & $83.7 \pm 24.6$ \\
\hline+ & + & + & SOD & $10.2 \pm 5.2$ & 92.5 \\
\hline+ & + & + & Catalase & $73.3 \pm 4.2$ & $13.2 \pm 8.4$ \\
\hline+ & + & + & Phenanthroline & $74.8 \pm 6.7$ & $78.7 \pm 15.0$ \\
\hline+ & + & + & DFT & $72.8 \pm 5.3$ & $80.1 \pm 8.2$ \\
\hline
\end{tabular}

$2.5 \times 10^{6}$ human peripheral lymphocytes (contaminated with up to $1 \%$ PMN's and $5 \%$ monocytes) were incubated in the presence or absence of PMA $(100 \mathrm{ng} / \mathrm{ml})$ and/or $5 \times 10^{6}$ neutroplasts for $1 \mathrm{~h}$ at $37^{\circ} \mathrm{C}$. Antioxidants $(1 \mathrm{mg} \mathrm{SOD}, 5,000 \mathrm{U}$ catalase, $100 \mu \mathrm{M}$ phenanthroline, $100 \mu \mathrm{M}$ DFT) were added 15 min before PMA stimulation. In parallel samples DNA strand breaks (reciprocal of \%D) and $\mathrm{H}_{2} \mathrm{O}_{2}$ production, determined by the PHPA assay, were measured. Mean and SD of at least three determinations, except for SOD which was added in two experiments.

ated extracellularly, and in fact demonstrate a DNA-protective role of MPO added extracellularly. A potential role of lipid peroxide intermediates in the formation of DNA damage has not been excluded.

\section{Definition of intracellular oxidant responsible for DNA strand breaks}

Effect of oxidant scavengers on $\mathrm{H}_{2} \mathrm{O}_{2}$ induced DNA strand breaks. To define the oxidant species that was ultimately responsible for the formation of DNA strand breaks, various scavengers of oxidant radicals were added to P388 D1 cells before the addition of $\mathrm{H}_{2} \mathrm{O}_{2}$. All scavengers were added $15 \mathrm{~min}$ before the addition of $\mathrm{H}_{2} \mathrm{O}_{2}$ except for vitamin $\mathrm{E}$ (alpha-tocopherol acetate, $10 \mu \mathrm{M}$ in $0.25 \%$ ethanol, final concentrations) which was added $24 \mathrm{~h}$ before harvesting the cells to allow incorporation. Under these conditions, vitamin $\mathrm{E}$ was incorporated as verified by HPLC separation of hexane extracts (46). The antioxidants used were: SOD, Tiron (50), and CuDIPS (51) a membrane permeable compound that scavenges $\mathrm{O}_{2}$; mannitol, ethanol, Na-benzoate, DMSO, DMTU,

Table IV. Influence of Myeloperoxidase on Poly-ADP-Ribose Polymerase Activity in Lymphocytes Exposed to Various Oxidants

\begin{tabular}{|c|c|c|c|c|c|}
\hline Cells & Additions & pADP-RP & $\begin{array}{c}\mathrm{H}_{2} \mathrm{O}_{2} \text { produced during } 30 \mathrm{~min} \\
\text { (PHPA) }\end{array}$ & $\begin{array}{c}\mathrm{H}_{2} \mathrm{O}_{2} \text { at } \\
30 \min \text { (FTC) }\end{array}$ & MPO \\
\hline & & $\mathrm{pmol} / 10^{6} \mathrm{c} / \mathrm{min}$ & nmol & & $m U / m l$ \\
\hline Lym & - & $1.4 \pm 1.3$ & 0 & $2.7 \pm 1.6$ & 0.1 \\
\hline Lym & PMA & $2.3 \pm 1.4$ & $5.0 \pm 3.1$ & $3.3 \pm 1.4$ & 2.4 \\
\hline Lym + PMN & - & $1.8 \pm 1.0$ & 0 & $2.4 \pm 0.9$ & 12.7 \\
\hline Lym + PMN & PMA & $7.4 \pm 3.5$ & $84.0 \pm 9.8$ & $6.1 \pm 2.0$ & 21.7 \\
\hline Lym + PMN + azide & PMA & $33.3 \pm 8.4$ & $157.0 \pm 19.1$ & $78.9 \pm 8.9$ & 0.8 \\
\hline Lym & $\mathrm{XO} / \mathrm{P}$ & $15.8 \pm 4.5$ & 86.5 & $90.4 \pm 18.0^{\ddagger}$ & 0.1 \\
\hline Lym + 10 mU MPO & $\mathrm{XO} / \mathrm{P}$ & $12.4 \pm 4.3$ & 87.4 & $50.0 \pm 17.0^{\ddagger}$ & 3.3 \\
\hline Lym + 50 mU MPO & $\mathrm{XO} / \mathrm{P}$ & $6.3 \pm 2.0$ & 85.1 & $14.3 \pm 3.2^{\ddagger}$ & 19.1 \\
\hline Lym + 100 mU MPO & $\mathrm{XO} / \mathrm{P}$ & $1.9 \pm 0.8$ & 89.2 & $4.0 \pm 2.1^{\ddagger}$ & 48.3 \\
\hline Lym + NP & - & $1.1 \pm 1.0$ & 0 & 3.2 & 1.5 \\
\hline Lym + NP & PMA & $12.2 \pm 4.2$ & $89.5 \pm 12.5$ & 8.4 & 2.0 \\
\hline Lym NP + azide & PMA & $60.5 \pm 10.5$ & $138.0 \pm 20.4$ & 88.6 & 1.0 \\
\hline Lym + NP + $40 \mathrm{mU}$ MPO & PMA & $13.1 \pm 3.2$ & 97 & 9.4 & 2.9 \\
\hline Lym + NP + $100 \mathrm{mU}$ MPO & PMA & $0.2 \pm 2.0$ & 100 & 12.5 & 20.2 \\
\hline $\mathrm{Lym}+\mathrm{NP}+200 \mathrm{mU} \mathrm{MPO}$ & PMA & $2.5 \pm 1.0$ & 95 & 8.1 & 50.8 \\
\hline Lym + NP + LF & PMA & $13.0 \pm 5.1$ & 95 & 10.4 & n.d. \\
\hline
\end{tabular}

$5 \times 10^{6}$ lymphocytes $(\mathrm{Lym})$ were incubated in the presence of $(a) 2 \mathrm{mU} X O / 1 \mathrm{mM}$ purine; $(b) 5 \times 10^{6} \mathrm{PMNs} \pm 100 \mathrm{ng} \mathrm{PMA}$; or $(c)$ in the presence of $1-1.5 \times 10^{7}$ neutroplasts (NP) for $30 \mathrm{~min}$ at $37^{\circ} \mathrm{C}$. The number of neutroplasts to be used was titrated to yield the same amount of $\mathrm{H}_{2} \mathrm{O}_{2}$ as that produced by $5 \times 10^{6} \mathrm{PMN}$. Azide was added at a concentration of $5 \mathrm{mM}$, iron saturated lactoferrin (LF) was $1 \mu \mathrm{M}$. In parallel samples, poly-ADP-ribose polymerase activity (pADP-RP), production of $\mathrm{H}_{2} \mathrm{O}_{2}$ and MPO activity were determined. Since MPO cannot compete with the concentration of horseradish peroxidase contained in the PHPA assay, $\mathrm{H}_{2} \mathrm{O}_{2}$ determined with this assay is a measure of $\mathrm{H}_{2} \mathrm{O}_{2}$ formation only. In addition, $\mathrm{H}_{2} \mathrm{O}_{2}$ concentrations present at $30 \mathrm{~min}$ were measured by the ferrithiocyanate method (FTC). Since the presence of cells led to almost complete consumption of $\mathrm{H}_{2} \mathrm{O}_{2}$ except in the presence of azide, $\mathrm{H}_{2} \mathrm{O}_{2}$ in the XO/P \pm MPO experiments $\left({ }^{\ddagger}\right)$ was determined in the absence of cells in order to determine $\mathrm{H}_{2} \mathrm{O}_{2}$ consumption by MPO. 
DMPO, and salicylate, which scavenges ${ }^{\circ} \mathrm{OH}(31,48,52)$; catalase that metabolizes $\mathrm{H}_{2} \mathrm{O}_{2}$; desferroxamine, desferrithiocine, DTPA and phenanthroline, which are Fe-chelators, and BHT and vitamin $\mathrm{E}$, which inhibit lipid peroxidation. ${ }^{\circ} \mathrm{OH}$ scavengers were used in increasing concentrations up to the point where they either became insoluble or induced a diminution in cell viability. Fe-chelators were used at $100 \mu \mathrm{M}$, a concentration sufficient to chelate all of the extra- and intracellular iron, which was $\sim 3 \mu \mathrm{M}$ as determined by atomic absorption, but low enough to largely avoid nonspecific chelation of other metals. The concentrations of tiron, CuDIPS and alpha-tocopherol acetate were those which had previously been shown to inhibit oxidative injury $(46,50,53)$.

The only compounds that effectively prevented DNA strand breaks after a 15-min incubation were catalase, desferrithiocine, and phenanthroline (Table V). BHT (50 $\mu \mathrm{M}$ in ethanol, $1 \%$ final concentration) caused DNA strand breaks by itself (results not shown). $5 \mathrm{mM}$ GSH added extracellularly had no protective effect. DMSO at high concentrations (1 M) and DMPO $(0.1 \mathrm{M})$ showed a moderate protective effect. Desferroxamine prevented DNA strand breaks only after overnight incubation to allow internalization (we were not able to measure uptake of desferroxamine over a 90 -min period).

$100 \mu \mathrm{M} \mathrm{FeSO}_{4} \pm 100 \mu \mathrm{M}$ EDTA added to the extracellular medium did not produce any increase in DNA strand breaks.

Table $V$. Influence of Oxidant Scavengers on the Formation of $\mathrm{H}_{2} \mathrm{O}_{2}$-induced DNA Strand Breaks in P388DI Cells

\begin{tabular}{|c|c|c|c|}
\hline $\begin{array}{l}\text { Scavenged } \\
\text { species }\end{array}$ & Scavenger & Concentration & $\begin{array}{l}\text { \% Inhibition } \\
\text { of DNA } \\
\text { strand breaks }\end{array}$ \\
\hline $\mathrm{O}_{2}^{-}$ & $\begin{array}{l}\text { SOD } \\
\text { TIRON } \\
\text { CuDIPS }\end{array}$ & $\begin{array}{l}1 \mathrm{mg} / \mathrm{ml} \\
10 \mathrm{mM} \\
20 \mu \mathrm{M}\end{array}$ & $\begin{array}{r}0 \\
0 \\
-9\end{array}$ \\
\hline $\mathrm{H}_{2} \mathrm{O}_{2}$ & Catalase & $5,000 \mathrm{U}$ & 100 \\
\hline$\cdot \mathrm{OH}$ & $\begin{array}{l}\text { DMTU } \\
\text { DMSO } \\
\text { DMSO } \\
\text { Ethanol } \\
\text { Na-benzoate } \\
\text { Mannitol } \\
\text { Salicylate } \\
\text { DMPO }\end{array}$ & $\begin{array}{l}800 \mathrm{mM} \\
1 \mathrm{M} \\
0.1 \mathrm{M} \\
0.33 \mathrm{M} \\
0.1 \mathrm{M} \\
0.5 \mathrm{M} \\
2 \mathrm{mM} \\
0.1 \mathrm{M}\end{array}$ & $\begin{array}{r}0 \\
36 \\
3 \\
-10 \\
8 \\
0 \\
5 \\
25\end{array}$ \\
\hline Fe chelator & $\begin{array}{l}\text { DFO (15 min incubation) } \\
\text { DFO (overnight } \\
\text { incubation) } \\
\text { DFT } \\
\text { DTPA } \\
\text { Phenanthroline }\end{array}$ & $\begin{array}{l}100 \mu \mathrm{M} \\
100 \mu \mathrm{M} \\
100 \mu \mathrm{M} \\
100 \mu \mathrm{M} \\
100 \mu \mathrm{M}\end{array}$ & $\begin{array}{r}86 \\
90 \\
-5 \\
74\end{array}$ \\
\hline $\begin{array}{l}\text { Lipid } \\
\text { Peroxides }\end{array}$ & $\begin{array}{l}\text { Vitamin } \mathrm{E} \text { (overnight } \\
\text { preincubation) }\end{array}$ & $20 \mu \mathrm{M}$ & 4 \\
\hline
\end{tabular}

$2 \times 10^{6} \mathrm{P} 388 \mathrm{D} 1$ cells $/ \mathrm{ml}$ were incubated with the respective scavenger for $15 \mathrm{~min}$ at $37^{\circ} \mathrm{C}$. A dose range of $\mathrm{H}_{2} \mathrm{O}_{2}(20,35,50,100 \mu \mathrm{M})$ was added to parallel samples in the presence and absence of the scavenger. After a 5 -min incubation at $37^{\circ} \mathrm{C}$ the samples were centrifuged for $10 \mathrm{~s}$, placed on ice and prepared for the determination of DNA strand breaks. Inhibition of strand break formation was calculated for the concentration of $\mathrm{H}_{2} \mathrm{O}_{2}$, which induced $50 \%$ DNA unwinding in cells in the absence of scavenger.
When P388 D1 cells were preincubated with $100 \mu \mathrm{M} \mathrm{FeSO}_{4}$ for $18 \mathrm{~h}$ before the addition of $\mathrm{H}_{2} \mathrm{O}_{2}$ an increase of intracellular Fe from $102 \pm 21 \mathrm{pmol} / 10^{6}$ cells to $1190 \pm 409 \mathrm{pmol} / 10^{6} /$ cells was observed. The percentage of alkaline stable DNA before the addition of $\mathrm{H}_{2} \mathrm{O}_{2}$ decreased from $74.8 \pm 2.8 \%$ to $59.9 \pm 3.9 \%$ in the iron loaded cells (mean $\pm \mathrm{SD}$ of four experiments). Addition of $\mathrm{H}_{2} \mathrm{O}_{2}$ to these Fe-loaded cells showed a 15-20\% increase of DNA strand breaks at all concentrations of $\mathrm{H}_{2} \mathrm{O}_{2}$ tested (between 20 and $100 \mu \mathrm{M}$ ) without a shift in the dose response.

These experiments indicate that intracellular iron is a necessary intermediate in the formation of DNA strand breaks by $\mathrm{H}_{2} \mathrm{O}_{2}$.

When PMA-stimulated neutroplasts rather than $\mathrm{H}_{2} \mathrm{O}_{2}$ were used to produce DNA strand breaks, the same scavengers were found to prevent DNA strand break formation. The target cells in this case were lymphocytes. Phenanthroline and desferrithiocine blocked DNA strand breakage to the same degree as catalase (Table III), although the amount of $\mathrm{H}_{2} \mathrm{O}_{2}$ measured extracellularly under these conditions was identical to that seen in the absence of these iron chelators. DMSO $(0.25$ $\mathrm{M}$, the highest concentration that did not inhibit $\mathrm{H}_{2} \mathrm{O}_{2}$ formation by the neutroplast) as well as $0.5 \mathrm{M}$ mannitol did not protect DNA strand break formation in the lymphocyte.

Determination of ${ }^{\circ} \mathrm{OH}$ formation in cells exposed to $\mathrm{H}_{2} \mathrm{O}_{2}$. To measure the formation of intracellular ${ }^{\circ} \mathrm{OH}$, a method utilizing ${ }^{\circ} \mathrm{OH}$ to convert salicylate to DHBA was used (see Methods), in which DHBA is detected by electrochemical means after isolation of DHBA by HPLC. This method allows determination of as little as $100 \mathrm{fmol}{ }^{\circ} \mathrm{OH}$ (32). To eliminate extracellular ${ }^{\circ} \mathrm{OH}$ formation, traces of iron $(2.5 \mu \mathrm{M}$ in untreated PBS) were removed from the buffers as described in Methods, utilizing chelex, yielding Fe content of $<0.3 \mu \mathrm{M}$ by atomic absorption. This level represented the reliable limit of detection of iron by this method. The nearly complete removal of iron was verified by determining if the extracellular buffers lost their capacity to support ${ }^{\circ} \mathrm{OH}$ formation after treatment with chelex. $100 \mu \mathrm{M} \mathrm{H}_{2} \mathrm{O}_{2}$ in the presence of $10 \mu \mathrm{M}$ ascorbate formed 37 pmol DHBA compounds/h per ml untreated buffer, but only $4 \mathrm{pmol} / \mathrm{h}$ after chelex treatment. No DHBA compounds could be detected in the absence of ascorbate as a reducing agent.

When P388 D1 cells were incubated for $30 \mathrm{~min}$ in the presence of $5 \mathrm{mM}$ salicylate in Fe-free medium, the background level of DHBA products of $2.5 \pm 3.5 \mathrm{pmol} / 5 \times 10^{6}$ cells increased to $27.2 \pm 2.0 \mathrm{pmol}$ in the presence of $200 \mu \mathrm{M} \mathrm{H}_{2} \mathrm{O}_{2}$. In the presence of azide these levels further increased to 38 pmol $/ 5 \times 10^{6}$ cells. When $50 \mu \mathrm{M} \mathrm{FeSO}_{4} / 100 \mu \mathrm{M}$ EDTA were added, $85 \mathrm{pmol}{ }^{\circ} \mathrm{OH}$ could be trapped. Addition of $100 \mu \mathrm{M}$ phenanthroline to $\mathrm{P} 388 \mathrm{D} 1$ cells in the absence of $\mathrm{H}_{2} \mathrm{O}_{2}$ failed to form ${ }^{\circ} \mathrm{OH}$. When $200 \mu \mathrm{M} \mathrm{H}_{2} \mathrm{O}_{2}$ was added to this same mixture, the peak of the 2,5-DHBA adduct was not observed, although a peak corresponding to 75 pmol 2,3-DHBA eluted at $13 \mathrm{~min}$. Whether this peak actually presented increased $\mathrm{OH}$ formation or represented "oxidized" phenanthroline could not be distinguished. $1 \mathrm{M}$ DMSO on the other hand largely inhibited ${ }^{\circ} \mathrm{OH}$ formation in the presence of $200 \mu \mathrm{M} \mathrm{H}_{2} \mathrm{O}_{2}(10.1$ pmol $/ 5 \times 10^{6}$ cells).

The capacity of ${ }^{\circ} \mathrm{OH}$, generated extracellularly, to contribute to the formation of DNA strand breaks was assessed. A $\mathrm{XO} /$ purine system $(2 \mathrm{mU} \mathrm{XO} / \mathrm{ml} ; 1 \mathrm{mM}$ purine $)$, generated $102 \mathrm{pmol}{ }^{\circ} \mathrm{OH}$ as determined by DHBA formation from sali- 
cylate over a period of $10 \mathrm{~min}$. The addition of $1.25 \mu \mathrm{M}$ ironsaturated lactoferrin increased the amount of ${ }^{\circ} \mathrm{OH}$ determined to $570 \mathrm{pmol}$ over the same period of time. However, the addition of the lactoferrin did not lead to an increase of DNA strand breaks (see Table IV).

$\mathrm{H}_{2} \mathrm{O}_{2}$-induced cell lysis in various target cells. The concentrations of $\mathrm{H}_{2} \mathrm{O}_{2}$ needed to induce DNA strand breaks were one to two orders of magnitude lower than those that would lead to cell lysis. 50\% of P388 D1 cells lysed over a period of 12 $h$ after the addition of a bolus of $300 \mu \mathrm{M} \mathrm{H} \mathrm{H}_{2} \mathrm{O}_{2} ; \mathrm{GM} 1380$ fibroblasts did not lyse with concentrations of $\mathrm{H}_{2} \mathrm{O}_{2}$ of $<2$ $\mathrm{mM}$. Fig. 3 shows cell viability in various target cells $5 \mathrm{~h}$ after the addition of $\mathrm{H}_{2} \mathrm{O}_{2}$. It is obvious that DNA damage occurred long before cell viability was affected.

Repair of oxidant-induced DNA strand breaks in various target cells. Since cells with damaged DNA survived, it was important to determine the capacity for DNA repair in various target cells. GM 1380 fibroblasts exposed to $100 \mu \mathrm{M} \mathrm{H}_{2} \mathrm{O}_{2}$ in D-MEM containing 10\% FCS were able to rejoin their DNA strand breaks during the next $2 \mathrm{~h}$ (Fig. 4) as earlier described for P388 D1 cells (54). The use of tissue culture media decreased the number of strand breaks as compared to those obtained in MGB (Fig. 1). If the cells were glutathione depleted before the addition of $\mathrm{H}_{2} \mathrm{O}_{2}$, they not only developed an increased number of strand breaks, but also showed a slower repair (Fig. $4 \mathrm{~A}$ ). This decreased rate of repair could not be explained by impairment of DNA repair with increased numbers of strand breaks as shown when cells were injured with $150 \mu \mathrm{M} \mathrm{H} \mathrm{H}_{2} \mathrm{O}_{2}$ to reach about the same number of strand breaks as seen in glutathione-depleted cells at $100 \mu \mathrm{M} \mathrm{H}_{2} \mathrm{O}_{2}$.

DNA repair in rabbit alveolar macrophages was considerably slower (Fig. $4 \mathrm{~B}$ ), and no repair of DNA strand breaks was observed in human peripheral mononuclear cells. When the human mononuclear cells were gamma-irradiated (600 rad), DNA repair was completed within the next 60 to $90 \mathrm{~min}$ (64 and unpublished observations). No repair, however, occurred during the first $4 \mathrm{~h}$ in mononuclear cells which were exposed to either a bolus of $40 \mu \mathrm{M} \mathrm{H}_{2} \mathrm{O}_{2}$ or $100 \mathrm{ng}$ PMA in RPMI 1640 (containing $10 \mathrm{mM}$ Hepes and 10\% FCS). Once DNA strand breaks were induced, they were not repaired even if catalase (Fig. $4 \mathrm{~B}$ ) or phenanthroline were added after $5 \mathrm{~min}$. The antioxidants protected only if they were added before the $\mathrm{H}_{2} \mathrm{O}_{2}$ (Fig. 4 B). Removal of monocytes from the lymphocyte preparations did not enhance DNA repair. Since persistence in DNA strand breaks could occur if cellular endonucleases were activated by the oxidant-induced initial DNA damage, various

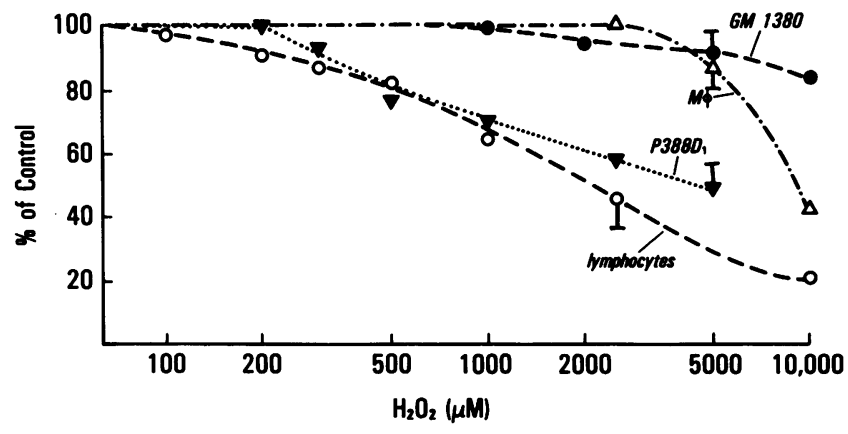

Figure $3.2 \times 10^{6}$ cells were incubated at $37^{\circ} \mathrm{C}$ in MGB. At $0 \mathrm{~h}$ a bolus of $\mathrm{H}_{2} \mathrm{O}_{2}$ was added. Cell viability was determined by trypan blue exclusion $5 \mathrm{~h}$ later. Error bars represent the SD of three separate experiments.
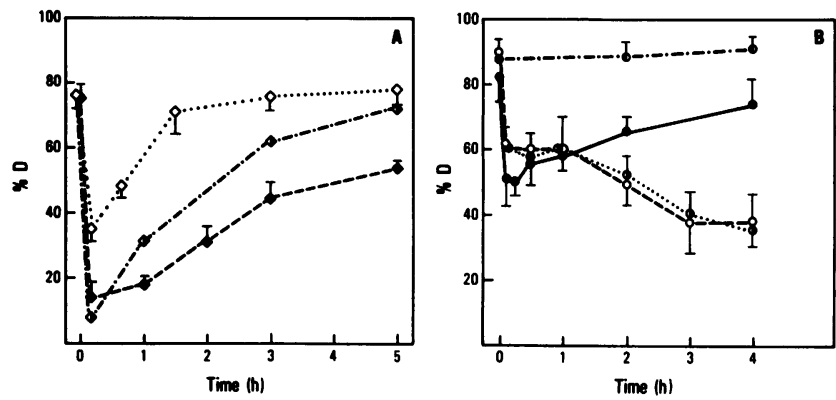

Figure 4. Repair of DNA strand breaks induced by $\mathrm{H}_{2} \mathrm{O}_{2}$ in various target cells: The cells were exposed to $\mathrm{H}_{2} \mathrm{O}_{2}$ for up to $5 \mathrm{~h}$ at $37^{\circ} \mathrm{C}$ in full culture media. DNA strand breaks were determined as explained (15). (A) Adherent GM1380 fibroblasts $\left(1 \times 10^{7} / 150 \mathrm{~cm}^{2} / 100 \mathrm{ml}\right.$ media) were exposed to $100 \mu \mathrm{M} \mathrm{H}_{2} \mathrm{O}_{2}(\diamond), 150 \mu \mathrm{M} \mathrm{H}_{2} \mathrm{O}_{2}(\diamond)$, or 100 $\mu \mathrm{M} \mathrm{H}_{2} \mathrm{O}_{2}$ in cells depleted of $97 \%$ of their glutathione $(\bullet)$ by overnight incubation with buthionine sulfoximine. Cells were trypsinized for $2 \mathrm{~min}$, centrifuged for $3 \mathrm{~min}$ at $400 \mathrm{~g}$ and analyzed for DNA strand breaks and described. $(B) 2 \times 10^{6} / \mathrm{ml}$ alveolar macrophages exposed to $200 \mu \mathrm{M} \mathrm{H}_{2} \mathrm{O}_{2}(\bullet) ; 2 \times 10^{6}$ mononuclear cells (75\% lymphocytes) exposed to $40 \mu \mathrm{M} \mathrm{H}_{2} \mathrm{O}_{2}$ (0), exposed to $40 \mu \mathrm{M} \mathrm{H}_{2} \mathrm{O}_{2}$ in the presence of 3,000 U catalase (0), or exposed to $40 \mu \mathrm{M} \mathrm{H}_{2} \mathrm{O}_{2}$ for 5 min and then treated with catalase (o). Mean and SD for three experiments in quadruplicate.

conditions of endonuclease inhibition were chosen: However, conditions that are known to inhibit endonucleases within lymphocytes (up to $5 \mathrm{mM}$ EDTA [54], $800 \mu \mathrm{M} \mathrm{ZnSO}{ }_{4}, 5$ $\mu \mathrm{g} / \mathrm{ml}$ cycloheximide [55]), incubation at $4^{\circ} \mathrm{C}$, failed to hasten the DNA repair (data not shown), nor did these additions influence the initial formation of DNA strand breaks.

\section{Discussion}

This study examines the question of which oxidants, generated external to cells, induce damage to DNA resulting in strand breakage; and which free radicals, formed intracellularly, after penetration of the oxidants, are responsible for the damage to DNA.

\section{Extracellular oxidants}

$\mathrm{H}_{2} \mathrm{O}_{2}$. The data indicate that of the spectrum of inflammatory oxidants generated by leukocytes the major extracellular oxidant causing DNA strand breakage after penetrating target cells, is $\mathrm{H}_{2} \mathrm{O}_{2}$. This was indicated by several sets of data: $\mathrm{H}_{2} \mathrm{O}_{2}$ in micromolar concentrations induced DNA strand breaks in a variety of target cells; catalase, but not other antioxidants, prevented DNA strand break formation in the presence of a variety of oxidants as well as the formation of 8-hydroxydeoxyguanosine, intracellular catalase provided primary protection to DNA damage in target cells by a variety of extracellular oxidants, and the susceptibility of target cells to oxidants was inversely related to their catalase content. These findings relating the presence of extracellular $\mathrm{H}_{2} \mathrm{O}_{2}$ and DNA damage of target cells parallel closely the relationship drawn by Nathan et al. $(4,56)$ between extracellular $\mathrm{H}_{2} \mathrm{O}_{2}$ and target cell lysis. In these latter studies, correlations of $\mathrm{H}_{2} \mathrm{O}_{2}$ concentration, together with the blocking effects on cytolysis by specific inhibition of $\mathrm{H}_{2} \mathrm{O}_{2}$ led to the conclusion that $\mathrm{H}_{2} \mathrm{O}_{2}$ was the inflammatory oxidant bearing greatest activity in target cell lysis. While it cannot be excluded that $\mathrm{H}_{2} \mathrm{O}_{2}$ induced endonuclease activation, no evidence of this event could be shown; especially there was no indication of the characteristic 180-mer DNA 
degradation ladder observed in target cells exposed to cytotoxic lymphocytes (55), when DNA from $\mathrm{H}_{2} \mathrm{O}_{2}$ exposed P388D1 cells was separated on agarose gels (data not shown).

$\mathrm{O}_{2}^{-},{ }^{\circ} \mathrm{OH}, \mathrm{HOCl}$. No additional DNA strand breaks were observed when cells were incubated with an $\mathrm{O}_{2}^{-}$producing system (XO/purine) rather than with a $\mathrm{H}_{2} \mathrm{O}_{2}$ producing system (GO/glucose). DNA strand breaks induced by xanthine oxidase/purine could be completely prevented by the addition of catalase, but not SOD, indicating that exposure of the cells to $\mathrm{O}_{2}^{-}$(in the absence of $\mathrm{H}_{2} \mathrm{O}_{2}$ ) does not lead to intracellular DNA strand breaks. $\mathrm{O}_{2}^{-}$can, however, augment the formation of DNA strand breaks in isolated DNA $(24,25)$ and may contribute to DNA damage in neutrophils, which generate $\mathrm{O}_{2}^{-}(57)$. The lack of target cell DNA strand break formation by extracellular $\mathrm{O}_{2}^{-}$thus may simply reflect a poor transport of $\mathrm{O}_{2}^{-}$to the nucleus. While it has been shown that $\mathrm{O}_{2}^{-}$can be taken up by cells through the anion channel in erythrocytes $(58)$, it is uncertain whether the rate of transport would be sufficient to lead to DNA damage. In contrast, $\mathrm{H}_{2} \mathrm{O}_{2}$ diffuses freely into cells (59) and is sufficiently nonreactive to reach the nucleus unless it is enzymatically degraded.

Extracellular ${ }^{\circ} \mathrm{OH}$ formed from iron-saturated lactoferrin in the presence of $\mathrm{XO} /$ purine failed to induce additional DNA strand breaks in target cells, suggesting that the ${ }^{\circ} \mathrm{OH}$ formed extracellularly cannot reach the nucleus.

$\mathrm{HOCl}$ in cytolytic concentrations $(200 \mu \mathrm{M})$ did not induce DNA strand breaks in whole cells or in isolated DNA (observations to be published). In addition, when myeloperoxidase (which converts $\mathrm{H}_{2} \mathrm{O}_{2}$ to $\mathrm{HOCl}$ in the presence of $\mathrm{Cl}^{-}$) was added to mixtures of target cells and $\mathrm{H}_{2} \mathrm{O}_{2}$, a diminution of DNA strand breaks of the target cell was observed in parallel with the diminished levels of $\mathrm{H}_{2} \mathrm{O}_{2}$ caused by conversion of the $\mathrm{H}_{2} \mathrm{O}_{2}$ to $\mathrm{HOCl}$ (Table IV).

\section{Protection of target cell DNA}

Cellular catalase appeared to play a major role in preventing $\mathrm{H}_{2} \mathrm{O}_{2}$-induced DNA strand breaks. With a variety of cell types a direct correlation existed between the susceptibility of oxidant-induced DNA strand breaks and the intracellular concentration of catalase and an inverse correlation between the half-life of $\mathrm{H}_{2} \mathrm{O}_{2}$ in the medium and the concentration of catalase. Inhibition of cellular catalase by azide or aminotriazole led to an increase in, and nearly equal susceptibility to DNA strand breaks in all cells. In the dose range of oxidant used in our experiments catalase is the major catabolizing pathway for $\mathrm{H}_{2} \mathrm{O}_{2}$ (60-62). Lower concentrations of $\mathrm{H}_{2} \mathrm{O}_{2}(<20 \mu \mathrm{M})$ are degraded largely by the glutathione cycle. Depletion of glutathione increased DNA strand breaks in GM 1380 fibroblasts. While no effect of BSO treatment in $\mathrm{H}_{2} \mathrm{O}_{2}$-induced DNA strand breaks was observed in P388 D1 cells, this could be explained by the fact that only $92 \%$ of the glutathione was depleted. The remaining GSH is sufficient to assure essentially normal glutathione cycle activity in these cells (9).

\section{Intracellular oxidants}

It has been shown in isolated DNA, in this and other laboratories, (23-25) that $\mathrm{H}_{2} \mathrm{O}_{2}$-induced DNA strand breaks are caused by the formation of the hydroxyl radical. Different lines of evidence in the present studies strongly suggest a role of ${ }^{\circ} \mathrm{OH}$ in the formation of DNA damage induced by extracellular $\mathrm{H}_{2} \mathrm{O}_{2}$ : (a) $\mathrm{H}_{2} \mathrm{O}_{2}$ induced the formation of 8-hydroxydeoxyguanosine, which implies $\mathrm{OH}$ is an intermediate; $(b)$ chelation of intracellular iron by cell permeable iron chelators (phenanthroline
[27], desferrithiocine, prolonged incubation with deferrioxamine) prevented DNA strand break formation by extracellular $\mathrm{H}_{2} \mathrm{O}_{2}$. In contrast, ${ }^{\circ} \mathrm{OH}$ scavengers showed little effect in the whole cells (63), even though they completely prevented DNA strand breaks in isolated PM 2 phage DNA (23). Since ${ }^{\circ} \mathrm{OH}$ reacts indiscriminately with any molecule and has a diffusion radius of $2.3 \mathrm{~nm}(22)$, one may assume that the ${ }^{\circ} \mathrm{OH}$ scavengers never reached the site of ${ }^{\circ} \mathrm{OH}$ attack right on the DNA. Since the rate constant for the reaction of various ${ }^{\circ} \mathrm{OH}$ scavengers (DMSO, ethanol, DMPO) $(64,65)$ is of the same order of magnitude as that of ${ }^{\circ} \mathrm{OH}$ with deoxyribose (66), and since nucleotides are present in molar concentrations in the nucleosome, it is not surprising that ${ }^{\circ} \mathrm{OH}$ scavengers could not compete efficiently in this reaction. In fact, the partially protective effect of $1 \mathrm{M}$ DMSO agrees with the prediction from the above calculation.

'OH formation was detected in whole cells exposed to $\mathrm{H}_{2} \mathrm{O}_{2}$ by adduction of salicylate to form dihydroxybenzoic acid, and measurement of the resultant product by electrochemical means. The yield of ${ }^{\circ} \mathrm{OH}$ that could be trapped was about six orders of magnitude lower than the concentration of $\mathrm{H}_{2} \mathrm{O}_{2}$ added to the cells, although it is unlikely that ${ }^{\circ} \mathrm{OH}$ was trapped quantitatively by the salicylate. It is likely that only a small percentage of the ${ }^{\circ} \mathrm{OH}$ detected was formed in close enough proximity to the DNA to cause DNA damage. However, very small amounts of ${ }^{\circ} \mathrm{OH}$ are sufficient to cause the DNA strand breaks observed: A dose of 500-rad gamma-irradiation, causes DNA strand breakage comparable to the amount observed in our experiments (67). It reportedly causes $\sim 600 \mathrm{DNA}$ strand breaks per cell (68). If every thousandth ${ }^{\circ} \mathrm{OH}$ formed in a cell, would lead to a DNA strand break this would mean that 1 pmol ${ }^{\circ} \mathrm{OH}$ formed per $10^{6}$ cells, could account for all the DNA strand breaks observed.

Thus neither the lack of protection by ${ }^{\circ} \mathrm{OH}$ scavengers (nor the inability to show ${ }^{\circ} \mathrm{OH}$ formation) exclude ${ }^{\circ} \mathrm{OH}$ as a mediator of oxidant-induced injury. It has been speculated that small amounts of transition metal are bound to DNA $(68,69)$. Although this has not been proven, it would explain the formation of DNA strand breaks and the inability of ${ }^{\circ} \mathrm{OH}$ scavengers to prevent these DNA strand breaks. This site-specific formation of DNA strand breaks due to deoxyribose cleavage has been demonstrated for bleomycin induced DNA damage (70, 71). Site-specific ${ }^{\circ} \mathrm{OH}$ formation with transition metals as catalysts has been invoked for a number of other $\mathrm{H}_{2} \mathrm{O}_{2}$-mediated examples of target cell damage (72).

SOD has been previously shown to protect from DNA strand breaks in isolated DNA exposed to XO/xanthine (24), presumably by preventing the $\mathrm{O}_{2}^{-}$induced reduction of $\mathrm{Fe}^{3+}$ to $\mathrm{Fe}^{2+}$ which in the presence of $\mathrm{H}_{2} \mathrm{O}_{2}$ reforms $\mathrm{Fe}^{3+}+{ }^{\circ} \mathrm{OH}$ $+\mathrm{OH}^{-}$. A number of cellular reductants, e.g., ascorbate, $\mathrm{GSH}$, $\mathrm{NAD}(\mathrm{P}) \mathrm{H}$, etc. $(34,73)$ may reduce $\mathrm{Fe}^{3+}$ inside whole cells so that $\mathrm{O}_{2}^{-}$may not be essential to augment the formation of ${ }^{\circ} \mathrm{OH}$ within cells.

\section{Comparison between concentrations of $\mathrm{H}_{2} \mathrm{O}_{2}$ causing DNA strand breakage and cell lysis}

Our current studies and those of others have shown that certain cells are very resistant to $\mathrm{H}_{2} \mathrm{O}_{2}$-induced cellular lysis (62). It is doubtful that even local concentrations of $\mathrm{H}_{2} \mathrm{O}_{2}$ in the proximity of stimulated PMNs are ever high enough to cause lysis of GM 1380 fibroblasts or rabbit alveolar macrophages. The concentration of $\mathrm{H}_{2} \mathrm{O}_{2}$ in the proximity of stimulated PMNs is, however, high enough to cause DNA damage in 
target cells. $100 \mu \mathrm{M} \mathrm{H}_{2} \mathrm{O}_{2}$, e.g., caused DNA strand breaks in GM 1380 fibroblasts incubated in full culture medium. Although these cells progressed through the cell cycle at a rate slower than normal (unpublished results) they eventually divided. By the time they divided, DNA strand breaks had been completely repaired although errors in replacement of bases may have occurred during the repair process. It has been described that Escherichia coli DNA polymerase I misreads 8hydroxydeoxyguanosine itself as well as pyrimidines next to it (74). This moiety thus represents a possible link between oxidant-induced DNA damage and mutagenesis and carcinogenesis (75).

\section{Repair of $\mathrm{H}_{2} \mathrm{O}_{2}$ induced DNA strand breaks}

$\mathrm{H}_{2} \mathrm{O}_{2}$-induced DNA strand breaks were generally repaired over a period of 2-3 h. Glutathione contributed to DNA strand break repair presumably by direct hydrogen transfer as has been described previously for gamma-irradiation induced DNA damage $(76,77)$. The lack of repair of DNA strand breaks in lymphocytes exposed to oxidants contrasts with their normal capacity to repair DNA strand breaks induced by gamma-irradiation (65, and unpublished observations).

In summary, leukocytes may be stimulated to produce $\mathrm{H}_{2} \mathrm{O}_{2}$ in sufficient concentration to induce alteration of DNA without necessarily leading to cell death. Surviving cells may be prone to mutagenesis and malignant transformation (19, 20). This DNA damage may represent a link between chronic inflammation and the formation of malignancies that has been observed in various inflammatory conditions such as ulcerative colitis, tuberculosis, schistosomiasis, osteomyelitis, and possibly cigarette smoking.

\section{Acknowledgments}

The technical assistance of Anna Harris and Ken Browne, and the secretarial assistance of Monica Bartlett is gratefully acknowledged.

This is publication 5227-IMM of the Department of Immunology. This work was supported by National Institutes of Health grants HL-23584 and AI-17354, Office of Naval Research Contract 105-837, a grant from the Couricil for Tobacco Research 764-H, and a fellowship from the Parker B. Francis Foundation.

\section{References}

1. Johnson K. J., J. C. Fantone III, J. Kaplan, and P. A. Ward. 1981. In vivo damage of rat lungs by oxygen metabolites. J. Clin. Invest. 67:983-993.

2. Till, G. O., K. J. Johnson, R. Kunkel, and P. A. Ward. 1982. Intravascular activation of complement and acute lung injury: dependency on neutrophils and toxic oxygen metabolites. J. Clin. Invest. 69:1126-1135.

3. Schraufstatter, I. U., S. D. Revak, and C. G. Cochrane. 1984. Proteases and oxidants in experimental pulmonary inflammatory injury. J. Clin. Invest. 73:1175-1184.

4. Nathan, C. F., S. C. Silverstein; L. H. Brukner, and Z. A. Cohn. 1979. Extracellular cytolysis by activated macrophages and granulocytes. II. Hydrogen peroxide as a mediator of cytotoxicity. J. Exp. Med. 149:100-113.

5. Simon, R. H., C. H. Scoggin, and D. Patterson. 1981. Hydrogen peroxide causes the total injury to human fibroblasts exposed to oxygen radicals. J. Biol. Chem. 256:7181-7186.

6. Weiss, S. J., J. Young, A. F. LoBuglio, and A. Slivka. 1981. Role of hydrogen peroxide in neutrophil-mediated destruction of cultured endothelial cells. J. Clin. Invest. 68:714-724.
7. Sachs, T., C. F. Moldow, P. K. Craddock, J. K. Bowers, and H. S. Jacob. 1978. Oxygen radical mediated endothelial cell damage by complement-stimulated granulocytes. An in vitro model of immune vascular damage. J. Clin. Invest. 61:1161-1167.

8. Spragg, R. F., D. B. Hinshaw, P. A. Hyslop, I. U. Schraufstatter, and C. G. Cochrane. 1985. Alterations in ATP and energy charge in cultured endothelial and P388D1 cells following oxidant injury. $J$. Clin. Invest. 76:1471-1476.

9. Schraufstatter, I. U., D. B. Hinshaw, P. A. Hyslop, R. G. Spragg, and C. G. Cochrane. 1985. Glutathione cycle activity and pyridine nucleotide levels in oxidant-induced injury of cells. J. Clin. Invest. 76:1131-1139.

10. Hyslop, P. A., D. B. Hinshaw, W. A. Halsey, I. U. Schraufstatter, J. H. Jackson, R. G. Spragg, R. D. Sauerheber, and C. G. Cochrane. 1988. Mechanisms of oxidant mediated cell killing: the glycolytic and mitochondrial pathways of ADP phosphorylation are major targets of $\mathrm{H}_{2} \mathrm{O}_{2}$ mediated injury. J. Biol. Chem. 263:1665-1675.

11. Hyslop, P. A., D. B. Hinshaw, I. U. Schraufstatter, L. A. Sklar, R. G. Spragg, and C. G. Cochrane. 1986. Intracellular calcium homeostasis during hydrogen peroxide injury to cultured P388D1 cells. $J$. Cell. Physiol. 129:356-366.

12. Hinshaw, D. B., L. A. Sklar, B. Bohl, I. U. Schraufstatter, P. A. Hyslop, M. W. Rossi, R. G. Spragg, and C. G. Cochrane. 1986. Cytoskeletal and morphologic impact of cellular oxidant injury. Am. J. Pathol. 123:454-464.

13. Badway, J. A., and M. L. Karnovsky. 1980. Active oxygen species and the functions of phagocytic leukocytes. Annu. Rev. Biochem. 49:695-726.

14. Slater, T. F. 1984. Free-radical mechanisms in tissue injury. Biochem. J. 222:1-15.

15. Schraufstatter, I. U., D. B. Hinshaw, P. A. Hyslop, R. G. Spragg, and C. G. Cochrane. 1986. Oxidant injury of cells: DNA strand breaks activate polyadenosine diphosphate-ribose polymerase and lead to depletion of nicotinamide adenine dinucleotide. J. Clin. Invest. 77:1312-1320.

16. Birnboim, H. C. 1982. DNA strand breakage in human leukocytes exposed to a tumor promoter, phorbol myristate acetate. Science (Wash. DC). 215:1247-1249.

17. Bradley, M. O., and L. C. Erickson. 1981. Comparison of the effects of hydrogen peroxide and $\mathrm{x}$-ray irradiation on toxicity, mutation, and DNA damage/repair in mammalian cells (V-79). Biochim. Biophys. Acta. 654:135-141.

18. Weitberg, A. B., S. A. Weitzman, E. P. Clark, and T. P. Stossel. 1985. Effects of antioxidants on oxidant-induced sister chromatid exchange formation. J. Clin. Invest. 75:1835-1841.

19. Zimmerman, R., and P. Cerutti. 1984. Active oxygen acts as a promoter of transformation in mouse embryo $\mathrm{C} 3 \mathrm{H} / 10 \mathrm{Ti} / 2$ fibroblasts. Proc. Natl. Acad. Sci. USA. 81:2085-2087.

20. Weitzman, S., A. B. Weitberg, E. P. Clark, and T. P. Stossel. 1985. Phagocytes as carcinogens: malignant transformation produced by human neutrophils. Science (Wash. DC). 227:1231-1233.

21. Armel, P. R., G. F. Strniste, and S. S. Wallace. 1977. Studies on Escherichia coli $\mathrm{x}$-ray endonuclease specificity. Roles of hydroxyl and reducing radicals in the production of DNA lesions. Radiat. Res. 69:328-338.

22. Hutchinson, F. 1985. Chemical changes induced in DNA by ionizing radiation. Prog. Nucl. Acid Res. 32:115-154.

23. Jackson, J. H., I. U. Schraufstatter, P. A. Hyslop, K. Vosbeck, R. Sauerheber, S. A. Weitzman, and C. G. Cochrane. 1987. Role of oxidants in DNA damage: hydroxyl radical mediates the synergistic DNA damaging effects of asbestos and cigarette smoke. J. Clin. Invest. 80:1090-1095, 1987.

24. Brawn, K., and I. Fridovich. 1987. DNA strand scission by enzymically generated oxygen radicals. Arch. Biochem. Biophys. 206:414-419.

25. Lesko, A., R. J. Lorentzen, and P. O. Ts'o. 1980. Role of superoxide in deoxyribonucleic acid strand scission. Biochemistry. 19:3023-3028. 
26. Roots, R., and S. Okada. 1975. Estimation of life times and diffusion distances of radicals involved in X-ray-induced DNA strand breaks or killing of mammalian cells. Radiat. Res. 64:306-320.

27. Filho, A. C. M., and R. Meneghini. 1985. Protection of mammalian cells by o-phenanthroline from lethal and DNA-damaging effects produced by active oxygen species. Biochim. Biophys. Acta. 847:82-89.

28. Böyum, A. 1968. Isolation of mononuclear cells and granulocytes from human blood. Scand. J. Clin. Lab. Invest. Suppl. 21:77-97.

29. Berkow, R. L., D. Y. Tzeng, L. V. Williams, and K. L. Baehner. 1983. The comparative responses of human polymorphonuclear leukocytes obtained by counterflow centrifugal elutriation and Ficoll-Hypaque density centrifugation. J. Lab. Clin. Med. 102:732-742.

30. Roos, D., A. A. Voetman, and L. J. Meerhof. 1983. Functional activity of enucleated human polymorphonuclear leukocytes. J. Cell Biol. 97:368-377.

31. Birnboim, H. C., and J. J. Jevcak. 1981. Fluorometric method for rapid detection of DNA strand breaks in human white blood cells produced by low doses of radiation. Cancer Res. 41:1889-1892.

32. Floyd, R. A., J. J. Watson, and P. K. Wong. 1984. Sensitive assay of hydroxyl free radical formation utilizing high pressure liquid chromatography with electrochemical detection of phenol and salicylate hydroxylation products. J. Biochem. Biophys. Methods 10:221235.

33. Maniatis, T., E. Fritsch, and J. Sambrook. 1982. Molecular cloning: A laboratory manual. Cold Spring Harbor Laboratory, Cold Spring Harbor, NY.

34. Kasai, H., and S. Nishimura. 1984. Hydroxylation of deoxyguanosine at the $\mathrm{C}-8$ position by ascorbic acid and other reducing agents. Nucleic Acids Res. 12:2137-2145.

35. Floyd, R. A., J. J. Watson, J. Harris, M. West, and P. K. Wong. 1986. Formation of 8-hydroxydeoxyguanosine, hydroxyl free radical adduct of DNA in granulocytes exposed to the tumor promoter, tetradeconylphorbolacetate. Biochem. Biophys. Res. Commun. 137:841846.

36. Guilbault, E. C., P. J. Brignac, Jr., and J. Juneau. 1986. New substrates for the fluorometric determination of oxidative enzymes. Anal. Chem. 40:1256-1261.

37. Hyslop, P. A., and L. A. Sklar. 1984. A quantitative fluorimetric assay for superoxide anion generation by human neutrophils. Anal. Biochem. 141:280-286.

38. Thurman, R. G., H. G. Ley, and R. Scholz. 1972. Hepatic microsomal ethanol oxidation, hydrogen peroxide formation and the role of catalase. Eur. J. Biochem. 25:420-430.

39. Aebi, H. 1974. Catalase. Methods Enzymatic Anal. 2:673-684.

40. Winterbourn, C. C., R. E. Hawkins, M. Brian, and R. W. Carrell. 1975. The estimation of red cell superoxide dismutase activity. J. Lab. Clin. Med. 85:337-341.

41. Paglia, D. E., and W. N. Valentine. 1967. Studies on the quantitative and qualitative characterization of erythrocyte glutathione peroxidase. J. Lab. Clin. Med. 70:158-169.

42. Brehe, J. E., and H. B. Burch. 1976. Enzymatic assay for glutathione. Anal. Biochem. 74:189-197.

43. Griffith, O. W. 1980. Determination of glutathione and glutathione disulfide using glutathione reductase and 2-vinyl-pyridine. Anal. Biochem. 106:207-212.

44. Griffith, O. W., and A. Meister. 1979. Potent and specific inhibition of glutathione synthesis by buthionine sulfoxide (S-mbutyl-homocysteine sulfoximine). J. Biol. Chem. 254:7558-7560.

45. Revak, S. D., C. L. Rice, I. U. Schraufstatter, W. A. Halsey, B. P. Bohl, R. M. Clancy, and C. G. Cochrane. 1985. Experimental pulmonary inflammatory injury in the monkey. J. Clin. Invest. 76:1182-1192.

46. Fariss, M. W., G. A. Pascoe, and D. J. Reed. 1985. Vitamin E reversal of the effect of extracellular calcium on chemically induced toxicity in hepatocytes. Science (Wash. DC). 227:751-754.

47. Althaus, F. R., S. D. Lawrence, G. L. Sattler, and H. C. Pitot.
1982. ADP-ribosyltransferase activity in cultured hepatocytes: interactions with DNA repair. J. Biol. Chem. 257:5528-5535.

48. Floyd, R. A., and C. A. Lewis. 1983. Hydroxyl free radical formation from hydrogen peroxide by ferrous iron-nucleotide complexes. Biochemistry. 22:2645-2649.

49. Albrich, J. M., C. A. McCarthy, and J. K. Hurst. 1981. Biological reactivity of hypochlorous acid: Implications for microbicidal mechanism of leukocyte myeloperoxidase. Proc. Natl. Acad. Sci. USA. 78:210-214.

50. Ueda, K., S. Kobayashi, J. Morita, and T. Komano. 1985. Site-specific DNA damage caused by lipid peroxidation products. Biochim. Biophys. Acta. 824:341-348.

51. deAlvare, L. R., K. Goda, and T. Kumura. 1976. Mechanism of superoxide anion scavenging reaction by bis-(salicylate)-copper (II) complex. Biochem. Biophys. Res. Commun. 69:687-694.

52. Richmond, R., B. Halliwell, J. Chanhan, and A. Darbin. 1981. Superoxide dependent formation of hydroxyl radicals: Detection of hydroxyl radicals by the hydroxylation of aromatic compounds. Anal. Biochem. 118:328-335.

53. Kensler, T. W., D. M. Bush, and W. J. Kozumbo. 1983. Inhibition of tumor promotion by a biomimetric superoxide dismutase. Science (Wash. DC). 221:75-77.

54. Schraufstatter, I. U., P. A. Hyslop, D. B. Hinshaw, R. G. Spragg, L. A. Sklar, and C. G. Cochrane. 1986. Hydrogen peroxide-induced injury of cells and its prevention by inhibitors of poly-(ADP-ribose) polymerase. Proc. Natl. Acad. Sci. USA. 83:4908-4912.

55. Cohen, J. J., and R. C. Duke. 1984. Glucocorticoid activation of a calcium-dependent endonuclease in thymocyte nuclei leads to cell death. J. Immunol. 132:38-42.

56. Nathan, C. F., L. H. Brukner, S. C. Silverstein, and Z. A. Cohen. 1979. Extracellular cytolysis by activated macrophages and granulocytes. I. Pharmacologic triggering of effector cells and the release of hydrogen peroxide. J. Exp. Med. 149:84-99.

57. Birnboim, H. C., and M. Kanabus-Kaminska. 1985. The production of DNA strand breaks in human leukocytes by superoxide anion may involve a metabolic process. Proc. Natl. Acad. Sci. USA. 82:6820-6824.

58. Lynch, R. E., and I. Fridovich. 1978. Permeation of the erythrocyte shown by superoxide radical. J. Biol. Chem. 253:4697-4699.

59. Chance, B., H. Sies, and A. Boveris. 1979. Hydroperoxide metabolism in mammalian organs. Physiol. Rev. 59:527-603.

60. Fantone, J. C., and P. A. Ward. 1982. Role of oxygen-derived free radicals and metabolites in leukocyte-dependent inflammatory reactions. Am. J. Pathol. 107:397-418.

61. Roos, D., R. S. Weening, S. R. Wyss, and H. E. Aebi. 1980. Protection of human neutrophils by endogenous catalase. J. Clin. Invest. 65:1515-1522.

62. O'Donnell-Tormey, J., C. J. De Boer, and C. F. Nathan. 1985. Resistance of human tumor cells in vitro to oxidative cytolysis. J. Clin. Invest. 76:80-86.

63. Finkelstein, E., G. M. Rosen, and E. J. Ranckman. 1980. Spin trapping of superoxide and hydroxyl radical: practical aspects. Arch. Biochem. Biophys. 200:1-16.

64. Klein, S. M., G. Cohen, and A. I. Cederbaum. 1981. Production of formaldehyde during metabolism of dimethyl sulfoxide by hydroxyl radical generating systems. Biochemistry. 20:6006-6012.

65. Gutteridge, J. M. C. 1987. Ferrous-salt-promoted damage to deoxyribose and benzoate. Biochem. J. 243:709-714.

66. McWilliams, R. S., W. C. Cross, J. G. Kaplan, and H. C. Birnboim. 1983. Rapid rejoining of DNA strand breaks in resting human lymphocytes after irradiation by low doses of ${ }^{60} \mathrm{Co}$ gamma rays or 14.6-MeV neutrons. Radiat. Res. 94:499-507.

67. Shall, S. 1985. ADP-ribosylation as a cellular control mechanism. In ADP-ribosylation of proteins. F. R. Althaus, H. Hilz, S. Shall, editors. Springer, Berlin. 9-29.

68. Goldstein, S., and G. Czapski. 1986. The role and mechanism of metal ions and their complexes in enhancing damage in biological 
systems or in protecting these systems from the toxicity of $\mathrm{O}_{2}^{-}$. J. Free Radical Biol. Med. 2:3-11.

69. Stoewe, R., and W. A. Prutz. 1987. Copper-catalyzed DNA damage by ascorbate and hydrogen peroxide: kinetics and yield. Free Radical Biol. Med. 3:97-105.

70. Burger, R. M., S. J. Projan, S. B. Horwitz, and J. Peisach. 1986. The DNA cleavage mechanism of iron-bleomycin. J. Biol. Chem. 261:15955-15959.

71. Rabow, L., J. Stubbe, J. W. Kozarich, and J. A. Gerlt. 1986. Identification of the alkaline-labile product accompanying cytosine release during bleomycin-mediated degradation of d(CGCGCG). $J$. Am. Chem. Soc. 108:7130-7131.

72. Halliwell, B., and J. M. C. Gutteridge. 1986. Oxygen free radicals and iron in relation to biology and medicine: Some problems and concepts. Arch. Biochem. Biophys. 246:501-514.

73. Van Stevenick, J. J., T. M. van der Zee, and A. R. Dubbelman. 1985. Site-specific and bulk-phase generation of hydroxyl radicals in the presence of cupric ions and thiol compounds. Biochem. J. 232:309-311.
74. Kuchino, Y., F. Fori, H. Kasai, H. Inoue, S. Iwai, K. Miura, E. Ohtsuka, and S. Nishimura. 1987. Misreading of DNA templates containing 8-hydroxydeoxyguanosine at the modified base and at adjacent residues. Nature (Lond.). 327:77-79.

75. Weitzman, S. A., A. B. Weitberg, E. P. Clark, and T. P. Stossel. 1985. Phagocytes as carcinogens: malignant transformation produced by human neutrophils. Science (Wash. DC). 227:1231-1233.

76. Adams, G. E., G. S. McNaughton, and B. D. Michael. 1968. Pulse-radiolysis of sulphur compounds. Part 2-Free radical repair by hydrogen transfer from sulphydryl compounds. Trans. Faraday Soc. 64:902-910.

77. Revesz, L., and E. P. Malaise. 1983. Significance of cellular glutathione in radioprotection and repair of radiation damage. In Functions of Glutathione: Biochemical, Physiological, Toxicological and Clinical aspects. A. Larrson, editor. Raven Press, NY.

78. Omann, G. M., W. N. Swann, Z. G. Oades, C. A. Parkos, A. J. Jesaitis, and C. A. Sklar. 1987. N-formyl peptide receptor dynamics, cytoskeletal activation, and intracellular calcium response in human neutrophil cytoplasts. J. Immunol. 139:3447-3455. 